\title{
NO DEFINITE EVIDENCE FOR HUMAN ENDOGENOUS RETROVIRAL HERV-W AND HERV-H RNAS IN PLASMA OF LATVIAN PATIENTS SUFFERING FROM MULTIPLE SCLEROSIS AND OTHER NEUROLOGICAL DISEASES
}

\author{
Dmitrijs Užameckis ${ }^{1,2}$ Svetlana Čapenko ${ }^{1}$, Ināra Logina ${ }^{3}$, Modra Murovska ${ }^{1}$, \\ and Jonas Blomberg 2 ,\# \\ ${ }^{1}$ Department of Oncovirology, Augusts Kirhenšteins Institute of Microbiology and Virology, Rīga Stradiṇš University, \\ Rātsupìtes iela 5, Rīga, LV-1067, LATVIA; \\ uzameckis@inbox.lv; scapenko@latnet.lv; modra@latnet.lv \\ 2 Section of Clinical Virology, Department of Medical Sciences, Uppsala University Hospital, \\ Dag Hammarskjölds väg 17, 75185 Uppsala, Sweden; \\ jonas.blomberg@medsci.uu.se \\ ${ }^{3}$ Department of Neurology and Neurosurgery, Rīga Stradinš University, Pilsoṇu iela 13-37, Rīga, LATVIA; \\ Inara.Logina@rsu.Iv \\ \# Corresponding author; jonas.blomberg@ medsci.uu.se
}

Contributed by Modra Murovska

\begin{abstract}
Multiple sclerosis (MS) is a neurological disease of unknown aetiology. Several research groups reported an increased level of human endogenous retroviruses HERV-W and HERV-H RNAs in cerebrospinal fluid, plasma and supernatants of cell cultures from MS individuals. To quantify the abundance of extracellular virion-associated HERV, RNAs in blood, plasma samples from Latvian MS patients, patients with other neurological diseases (OND), as well as blood donors (BD), were retrospectively studied by using both our previously published and newly developed quantitative Real-time reverse transcription PCR assays (QPCRs) targeting different polymerase (pol) gene regions of HERV-W and HERV-H. Unspecific signals due to incomplete removal of DNA were monitored by running the assays with and without reverse transcription (RTI) in parallel. According to our score, a few MS, OND and healthy controls gave borderline signals simultaneously with both newly developed HERV-H and HERV-W QPCRs, but the rest were negative. All borderline positive samples also had small amounts of non-retroviral cellular mRNA with possible origin from cell-free circulating RNA fragments, apoptotic bodies or exosomes, which can mimic the previously described virus-like particles. The results do not confirm the previous reports on prevalence of HERV-H or -W virion-associated RNA in plasma of MS patients.
\end{abstract}

Key words: endogenous retrovirus, multiple sclerosis, plasma, real-time PCR, RNA.

\section{INTRODUCTION}

Multiple sclerosis (MS) is a progressive chronic inflammatory demyelinating disease of the central nervous system of still unknown etiology, where genetic and environmental factors (including infectious agents as a component), as well as autoimmunity, may be involved (Compston and Coles, 2008). In Latvia, there are no recent internationally published data on the MS prevalence rate, albeit the last study showed it was the highest among other Baltic States and rather close to the epidemiology within a "Fennoscandian focus" of high MS prevalence (Kurtzke, 2000; Pugliatti et al., 2006). It has been suggested that human endogenous retroviruses (HERVs) could trigger the aetiopathogenesis of
MS, see e.g. (Blomberg et al., 2005). So-called "virus-like particles" containing reverse transcriptase and retroviral RNA have been reported by several research groups in supernatants from cultured monocytes, B, T and leptomeningeal cells, as well as in cerebrospinal fluid and sera or plasma from MS patients ( Perron et al., 1989; 1991; Haahr et al., 1994; Munch et al., 1995; Christensen et al., 1997; Perron et al., 1997; Garson et al., 1998; Christensen et al., 1999; 2000; Serra et al., 2001; Christensen et al., 2002; Dolei et al., 2002; Nowak et al., 2003; Christensen, 2005; de Villiers et al., 2006; Arru et al., 2007). However, in some studies they were also detected in blood from non-MS individuals (Garson et al., 1998) including patients with 
other neurological diseases (OND) (Dolei et al., 2002). According to these data the detected retroviral RNAs preferably belong to the HERV-W or HERV-H groups (Perron et al., 1997; Komurian-Pradel et al., 1999; Christensen et al., 2000; Perron et al., 2000; Christensen, 2005). Nevertheless, the real nature and functions of the observed particles are still in need of clarification (Froussard, 1995). The goal of this paper was to check the abundance of extracellular HERV-W and HERV-H RNAs in blood circulation of MS patients versus controls. We used both previously published (Forsman et al., 2005) and newly developed sets of broadly targeting, highly sensitive, quantitative reverse transcription real-time PCRs (QPCRs).

\section{MATERIALS AND METHODS}

Special methodological precautions. There are many methodological "pitfalls" in HERV molecular studies, which in conjunction with highly sensitive techniques (e.g., QPCRs), may easily cause false-positive results. Even a single human DNA molecule is a rich source of amplifiable HERV sequences (Tristem, 2000; Gifford and Tristem, 2003). Thus, to avoid any reagent and sample contamination with exogenous human DNA from laboratory personnel and environment we observed strict anti-contamination routines throughout the entire pre-PCR and PCR steps, which were performed in physically separated rooms within UV-protected laminar and PCR hoods (Lo and Chan, 2006; Tamariz et al., 2006). All working surfaces and equipment were frequently decontaminated with UV irradiation (Ou et al., 1991) and DNA AWAYTM/RNase AWAY® solutions (Molecular BioProducts Inc., USA) or sodium hypochlorite (bleach).

Clinical samples. Thirty-seven patients with MS (25 females, 12 males), 20 patients ( 8 females, 12 males) with acute or chronic inflammatory demyelinating polyneuropathies (IDP), 6 patients ( 3 females, 3 males) with other non-inflammatory neurological disorders of the CNS (ONIND), 17 patients ( 9 females, 8 males) with non-inflammatory peripheral neuropathies (majority of them spondylogenic radiculopathies) (NIPN) and 25 randomly selected blood donors (BD) (13 females, 12 males) were included in this investigation (Table 1). The 43 IDP, ONIND and NIPN patients were collectively called OND (other neurological diseases). The mean age of the patients with MS was 37 years (16-59 years), of the patients with IDP - 34 years (15-61), of the patients with ONIND -29 years (15-68), of the patients with NIPN - 40 years $(15-54)$ and of the blood donors - 37 years (18-60). The cohorts were established with the approval of the Ethics Committee of Riga Stradiňš University and all participants gave informed consent before the examination. A clinical diagnosis of MS was established according to the revised criteria of McDonald (Polman et al., 2005). The patients were considered to have acute inflammatory lesion (positive Gd-enhancing lesions) when areas of hyperintensity, compared with surrounding brain parenchyma, were recorded on a T1-weighted MRI scan after i.v. injection of gadolinium-DTPA $(0.1 \mathrm{mmol} / \mathrm{kg}$

\section{PERSONS INCLUDED IN THE EXAMINATION}

\begin{tabular}{|c|c|}
\hline Patients with multiple sclerosis: & MS \\
\hline 1) Relapsing/Remitting & MSRR \\
\hline $\begin{array}{l}\text { a) in relapse } \\
\text { b)in remission }\end{array}$ & \\
\hline 2) Secondary Progressive & MSSP \\
\hline $\begin{array}{l}\text { a) in relapse } \\
\text { b) in relative stability }\end{array}$ & \\
\hline 3) Primary Progressive & MSPP \\
\hline $\begin{array}{l}\text { Other non-demyelinating neurological disorders of } \\
\text { CNS }\end{array}$ & ONIND \\
\hline Inflammatory demyelinating polyneuropathy: & IDP \\
\hline $\begin{array}{l}\text { 1) Acute inflammatory demyelinating } \\
\text { polyneuropathy }\end{array}$ & \\
\hline $\begin{array}{l}\text { 2) Chronic inflammatory demyelinating } \\
\text { polyneuropathy }\end{array}$ & \\
\hline Non-inflammatory peripheral neuropathy & NIPN \\
\hline Blood donors & $\mathrm{BD}$ \\
\hline
\end{tabular}

body weight). Active disease was defined as a clinical exacerbation and the presence of active inflammatory lesions on MRI (positive Gd- enhancing lesions); quiescent (inactive) disease phase was defined as a clinical remission in the relapsing/remitting MS and as relative stability in the secondary progressive MS. All patients of the IDP group met the criteria of Ashbury and Cornblath for the Guillain-Barré syndrome and for chronic IDP (Asbury and Cornblath, 1990). The type of nerve damage was estimated by nerve conduction studies.

In order to obtain virtually cell-free plasma all EDTAanticoagulated blood samples were centrifugated at $1600 \times$ $\mathrm{g}$ for $10 \mathrm{~min}$ at $4{ }^{\mathrm{O}} \mathrm{C}$ and supernatants were collected. This was followed by a second centrifugation at $16000 \times \mathrm{g}$ for $10 \mathrm{~min}$ at $4{ }^{\circ} \mathrm{C}$ to completely remove any cellular debris. The clarified plasma samples were further treated with 0.4 $\mu \mathrm{g} / \mu \mathrm{l}$ recombinant ribonuclease A (RNase A)(Ambion, UK) for $10 \mathrm{~min}$ at $37^{\circ} \mathrm{C}$ to avoid any possible contamination by cellular RNA-containing endogenous retroviral sequences (Dolei et al., 2002).

RNA purification. The expected viral RNAs were extracted from $250 \mu \mathrm{l}$ of plasma samples by using the Tri$\mathrm{zol}^{\circledR}$ LS Reagent (Invitrogen Life Technologies, USA), as described by the manufacturer, with some modifications. Briefly, to remove high molecular weight DNA, after addition of a sample to Trizol, an additional centrifugation at $12000 \times \mathrm{g}$ for 10 minutes at $4{ }^{\circ} \mathrm{C}$ was performed. The cleared solution was transferred to a clean tube and $100 \mu \mathrm{l}$ of 1-bromo-3-chloropropane (BCP) (Sigma-Aldrich, USA), instead of chloroform, was added (Chomczynski and Mackey, 1995). Prior to precipitation of the RNA with isopropanol, $15 \mu \mathrm{g}$ of GlycoBlue (Ambion, UK) as a carrier 
was added to the aqueous phase. Finally, the RNA pellet was dissolved in $20 \mu \mathrm{l}$ of RNase-free water. For all preparations 100000 copies of an exogenous internal control (EIC) pAW109 RNA (Applied Biosystems, USA) were doped to the Trizol ${ }^{\circledR}$ LS reagent to monitor the efficiency of RNA extraction, possible RNA degradation during DNase treatment and presence of RT-PCR inhibitors. To eliminate possible DNA contamination, all RNA preparations $(20 \mu \mathrm{l})$ were rigorously treated with hyperactive, recombinant DNase according to the manufacturer's recommendations for the TURBO DNA-free ${ }^{\mathrm{TM}}$ kit (Ambion, UK).

RT-PCR assays. $10 \mu \mathrm{l}$ of each plasma RNA sample was reverse transcribed (RT+) in a volume of $25 \mu$ l containing 50 $\mathrm{mM}$ Tris- $\mathrm{HCl}(\mathrm{pH} 8.3), 10 \mathrm{mM}$ dithiothreitol (Promega, USA), $75 \mathrm{mM} \mathrm{KCl,} 3 \mathrm{mM} \mathrm{MgCl}_{2}, 800 \mu \mathrm{M}$ of each dNTP (Amersham Pharmacia Biotech, Sweden), 265 ng of random hexamer oligonucleotides (Amersham Pharmacia Biotech, Sweden), $40 \mathrm{U}$ of recombinant RNase Inhibitor (Promega, USA) and 25U of StrataScript reverse transcriptase (Stratagene, USA) at $25 \mathrm{oC}$ for $10 \mathrm{~min}, 42{ }^{\circ} \mathrm{C}$ for $60 \mathrm{~min}$ and 95 ${ }^{\circ} \mathrm{C}$ for 5 min followed by chilling on ice. Controls without reverse transcription (RT-) to check for cellular DNA contamination were included for every sample. For all subsequent QPCR reactions $2 \mu \mathrm{l}$ of the cDNA sample was used per $25 \mu \mathrm{l} \mathrm{PCR}$ reaction. Thus, to estimate the number of HERV RNA copies per ml of plasma (viral loads), the number of copies per PCR reaction had to be multiplied with 100.

Prior to QPCRs $2 \mu \mathrm{l}$ of each RT+ preparation was amplified with a primer pair DM151/152 (Applied Biosystems, USA) spanning an IL- $1 \alpha$ region of synthetic EIC, as described by the manufacturer. Additionally, all samples were analysed by a "PAN-retrovirus" seminested PCR system with human DNA as a positive amplification control (Perron et al., 1997; Tuke et al., 1997). The resulting RT-PCR products were respectively analysed by $1.5 \%$ or $2.5 \%$ agarose gel electrophoresis with ethidium bromide staining.

The human tissue RNA panel from ClonTech (Human total RNA master panel II, catalogue number K4008-1) was also used for evaluation our new QPCRs. As described by the manufacturer, each tissue RNA sample was pooled from several persons, and thus represents an average. For each RNA preparation, $2 \mu \mathrm{g}$ RNA was used to produce $50 \mu \mathrm{l}$ of
cDNA, as described above. In each subsequent QPCR reaction, $2 \mu \mathrm{l}$ of cDNA was used.

QPCRs. Two reverse transcriptase (RT) motif-based HERV-H and -W group-specific QPCRs used in this study were described earlier (Forsman et al., 2005) and two novel confirmatory assays, targeting conserved portions of the carboxyl- (HERV-W) and aminoterminal (HERV-H) portions of the evolutionary conserved polymerase ( $\mathrm{pol}$ ) gene, were developed and characterised according to the MIQE guidelines (Bustin et al., 2009). Briefly, four consensus primers and two TaqMan ${ }^{\circledR}$ (hydrolysis) dual-labeled probes (Table 2) theoretically detecting the expression of a majority of HERV-H and -W loci were designed from the multiple alignments of HERV-W (Fig. 1) and HERV-H (Fig. 2) pol genes generated by the ClustalW programme (Thompson et al., 1994). The included proviral sequences were obtained from the GenBank database using the BLAST network server (Altschul et al., 1997), as also derived from the RetroTector $^{(}$bioinformatics programme (Sperber et al., 2007; 2009) and the literature (Perron et al., 1997; Tristem, 2000; Kim, 2001; Jern et al., 2004; 2005).

The specificity of the selected oligonucleotides was verified by BLAST searching, cloning of PCR products amplified from genomic DNA and sequencing of a number of randomly selected clones. The cloning frequencies of the amplimers relative to target abundance in the human genome did not indicate predominant amplification of some HERV loci against others (D. Uzameckis, unpublished results). The quantification was made by interpolation in standard curves of dilutions of synthetic, entire pol gene-containing HERV-H (GenBank accession no. AF026252, nucleotide positions 41-245) (Lindeskog et al., 1998) and HERV-W (GenBank accession no. AF009668, nucleotide positions 1680-2150) (Perron et al., 1997) plasmids (Integrated DNA Technologues Inc., USA), as well as from a previously constructed histone 3.3C plasmid control (Andersson et al., 2005). All QPCR reactions were performed in duplicates in a Corbett Rotorgene (Corbett Research, Australia) real-time thermocycler in a total volume of $25 \mu$, containing $1 \times$ TaqMan PCR Universal Master Mix, No UNG with $0.05 \mathrm{U}$ of $\mathrm{HK}^{\mathrm{TM}}-\mathrm{UNG}$ Thermolabile Uracil N-Glycosylase (EPICENTRE, USA) (Longo et al., 1990; Pruvost et al., 2005) and $2 \mu$ of each cDNA preparation. Reagent or non-template controls were performed be-

Table 2 DESIGNED QPCRS OLIGONUCLEOTIDES

\begin{tabular}{|c|c|c|c|c|}
\hline HERV group & $\begin{array}{l}\text { pol } \\
\text { motif }\end{array}$ & $\begin{array}{l}\text { Sequence }^{\psi} \\
\left(5^{\prime} \rightarrow 3^{\prime}\right)\end{array}$ & Degeneracy & $\begin{array}{l}\text { Optimal } \\
\text { concentrations (nM) }\end{array}$ \\
\hline HERV-H & integrase & $\begin{array}{l}\text { Fw: gaYaagIcttacaRRttagttca } \\
\text { Rev: ttKggcaccaYRgggt } \\
\text { Probe: tctRYgYctt*atcaaccaaattgtttt }\end{array}$ & $\begin{array}{l}8 \\
8 \\
8\end{array}$ & $\begin{array}{l}300 \\
300 \\
200\end{array}$ \\
\hline HERV-W & integrase & $\begin{array}{l}\text { Fw: } \quad \text { taYctagtcctccatgcc } \\
\text { Rev: } \quad \text { ctaatRRcttcctgatgKttgata } \\
\text { Probe: aatatggagagaaagggaat*Kcctaacttc }\end{array}$ & $\begin{array}{l}2 \\
8 \\
2\end{array}$ & $\begin{array}{l}300 \\
300 \\
100\end{array}$ \\
\hline
\end{tabular}

QPCRs, Real-time reverse transcription polymerase chain reaction assays; HERV, human endogenous retroviruses; ${ }^{\psi} \mathrm{IUPAC}$ ambiguity codes: $\mathrm{Y}=\mathrm{C} / \mathrm{T}, \mathrm{R}=$ $\mathrm{A} / \mathrm{G}, \mathrm{K}=\mathrm{G} / \mathrm{T}, \mathrm{I}=\mathrm{Inosin}$; *position of internal dark quencher 


\section{HERV-W}

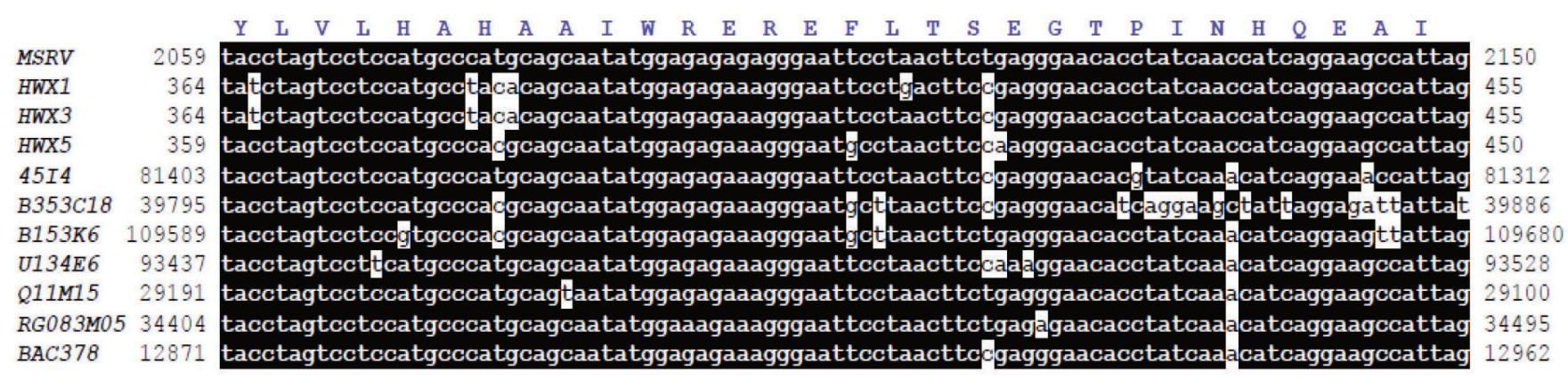

Fig. 1. Alignment of a conserved portion of the integrase domain at the carboxy terminus of the polymerase genes of selected representatives of the HERV-W group. Sequences were obtained from the literature (Kim, 2001; Perron et al., 1997) and our own BLAST searches in Genbank. Genbank accession numbers: MSRV (AF009668) (translation was derived from it), HWX1 (AB021919), HWX3 (AB021920), HWX5 (AB021921), 45I4 (AL023581), B353C18 (AC004066), B153K6 (AC005187), U134E6 (Z83850), Q11M15 (AF045450), RG083M05 (AC000064), BAC378 (U85196). HERV, human endogenous retroviruses.

fore and after each clinical sample, as well as a corresponding negative RT- control for each sample was included.

Optimal concentrations of the selected primers and TaqMan ${ }^{\circledR}$ probes were determined according to the TaqMan ${ }^{\circledR}$ PCR Universal Master Mix guidelines (Applied Biosystems, USA) (data not shown). For subsequent QPCR reactions final concentrations of $300 \mathrm{nM}$ of each primer and $100 \mathrm{nM}(\mathrm{HERV}-\mathrm{W})$ or $200 \mathrm{nM}(\mathrm{HERV}-\mathrm{H})$ of the probe were used (Table 2).

For HERV-W QPCR, the lowest threshold cycle $(\mathrm{Ct})$ and highest reduced normalised fluorescence $\left(\Delta R_{n}\right)$ were observed at $50{ }^{\circ} \mathrm{C}$ (data not shown). An optimal annealing temperature of $50{ }^{\circ} \mathrm{C}$ was therefore chosen to broadly amplify many HERV-W loci. Final QPCR parameters were 50 ${ }^{\circ} \mathrm{C}$ for $3 \mathrm{~min}, 95^{\circ} \mathrm{C}$ for $10 \mathrm{~min}$, followed by 60 cycles of 95 ${ }^{\circ} \mathrm{C}$ for $15 \mathrm{~s}, 50{ }^{\circ} \mathrm{C}$ for $30 \mathrm{~s}$ and $72{ }^{\circ} \mathrm{C}$ for $30 \mathrm{~s}$. During the optimisation, gradient PCR reactions were performed at different annealing temperatures from $50{ }^{\circ} \mathrm{C}$ to $60{ }^{\circ} \mathrm{C}$ with an increment of $1{ }^{\circ} \mathrm{C}$. The same amount of human genomic DNA (30 ng per PCR reaction) was used as a template during all optimisation experiments.

For HERV-H QPCR, no significant difference in the threshold cycles (Cts) or $\Delta \mathrm{Rn}$ was observed at different annealing temperatures (data not shown). Final QPCR parameters were $50{ }^{\circ} \mathrm{C}$ for $3 \mathrm{~min}, 95^{\circ} \mathrm{C}$ for $10 \mathrm{~min}, 60$ cycles of $95^{\circ} \mathrm{C}$ for $15 \mathrm{~s}$ and $60{ }^{\circ} \mathrm{C}$ for $1 \mathrm{~min}$. The PCR optimisation procedure was otherwise the same as described for HERV-W. The linearity and sensitivity of the developed assays were ascertained by generation of a standard curve with serial plasmid DNA dilutions $\left(10^{0}-10^{7}\right.$ copies/reaction with 10 -fold increment). Although an exact quantification through these real-time PCRs cannot be expected due to measurement of DNA rather than RNA and frequent mutations in primer and probe target sequences of members of these two HERV groups, we subsequently refer to them as quantitative PCRs (QPCRs). Sensitivity of both new assays was 1-10 nucleic acid equivalents of plasmid DNA standards or down to $100 \mathrm{fg}$ of human genomic DNA per PCR reaction (data not shown), which corresponds to a detection limit for the whole system of approximately 100-1000 viral RNA copies per $\mathrm{mL}$ of plasma, conservatively counting one HERV DNA copy equal to one HERV RNA copy. For simplicity we use the word "RNA equivalents" for clinical samples even if the available standards were DNAs and the QPCR reactions were preceded by a reverse transcription step (two-step RT-PCR). Lacking a more precise quantification, these correspond to "cDNA copies".

The efficiencies of the developed HERV-H and HERV-W QPCRs were $98 \%$ (slope $-3.37, \mathrm{r}^{2}>0.99$ ) and $95 \%$ (slope $\left.-3.45, \mathrm{r}^{2}>0.99\right)$, respectively.

The obtained results were scored as:

(1). negative: if a RT+ signal lower than 10 nucleic acid equivalents per PCR reaction was observed, or signals of similar strength occurred in the RT+ and the RT- reactions;

(2). borderline: if the RT+ signal was from 10 till 99 nucleic acid equivalents per PCR reaction and the RT- signal was negative or less than $1 / 10$ of the RT+ signal;

(3). clearly positive: if the RT+ signal was 100 nucleic acid equivalents per PCR reaction or more, and the RT- signal was negative or less than $1 / 10$ of the RT+ signal.

In spite of a much lower RT- signal, there is a considerable uncertainty in the borderline zone, both due to the stochastic nature of the signal in this range and the somewhat uncertain contribution of cellular DNA or cDNA to the signal. As a confirmatory test, all QPCR products were electrophoretically resolved in $2 \%$ preparative agarose gels and stained with ethidium bromide. The PCR results were obtained in Uppsala before the identity of the samples was revealed from Latvia. 


\section{HERV-H}

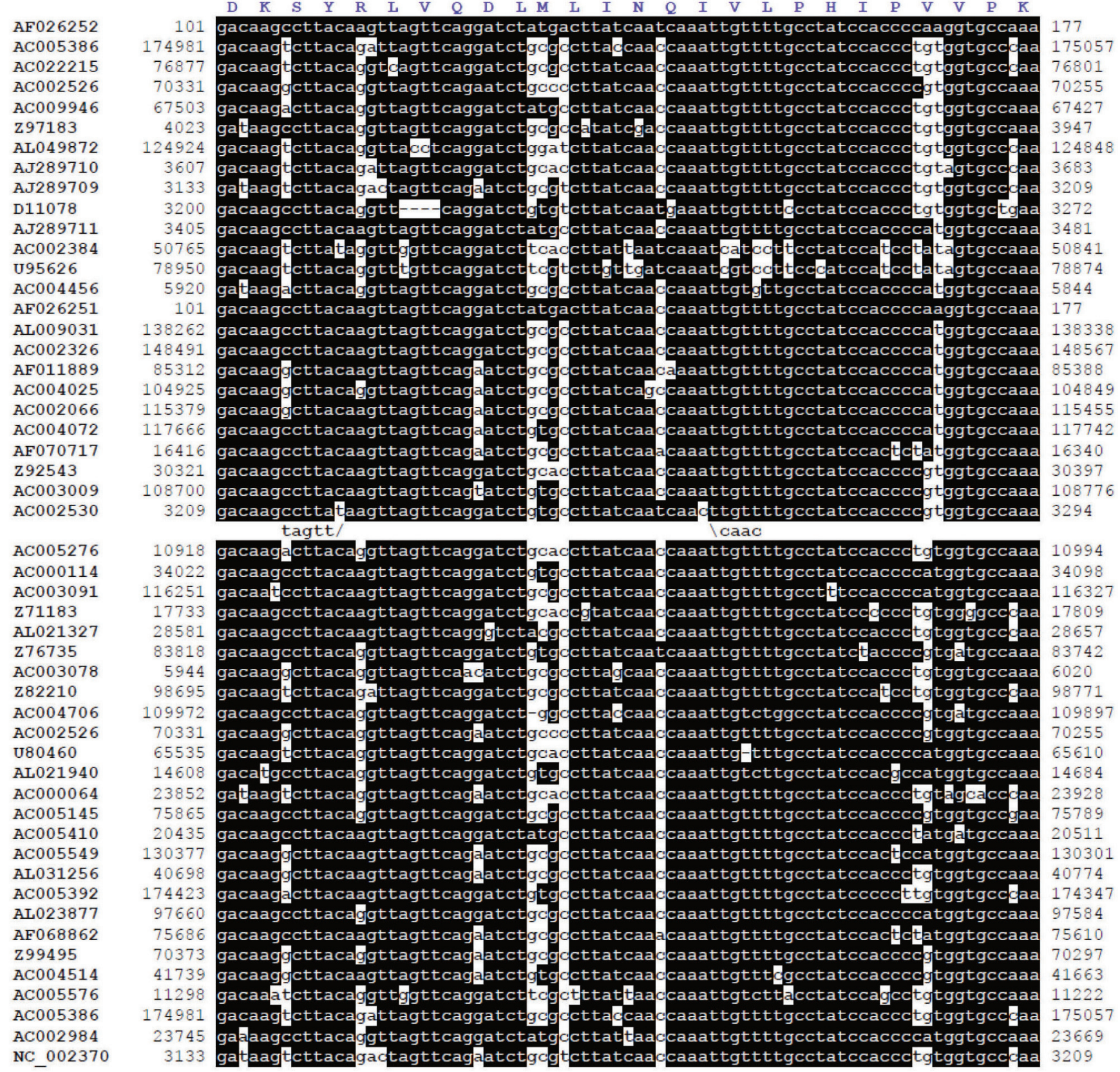

gaYaagIcttacaRRctagttca tctRYgYcttatcaaccaaattgtttt acccYRtggtgccMaa

$\left(5^{\prime}-\right.$ ttKggcaccaYRgggt $\left.-3^{\prime}\right)$

Fig. 2. Alignment of amino termini of HERV- H sequences. GenBank entries were partially obtained from Tristem (2000) and our own BLAST searches in GenBank. HERV, human endogenous retroviruses.

The QPCRs were also used to study HERV-H and HERV-W expression in twenty different human tissues. No RNA reference was used. In other studies, we measured histone 3.3 C (Andersson et al., 2005), as also UBC, HPRT, and GAPDH (Vandesompele et al., 2002) housekeeping genes mRNA expression levels in the same tissue RNA panel samples. The most evenly expressed gene per $\mu \mathrm{g}$ of RNA was histone $3.3 \mathrm{C}$ (data not shown). The relative expression pattern became essentially the same with and with- out normalisation against histone $3.3 \mathrm{C}$. In this paper, we therefore chose not to perform the normalisation.

Statistical analysis. The Freeman-Halton extension of two-tailed Fisher's exact test was used to analyse differences in categorical variables (Freeman and Halton, 1951; Soper, 2015), as well as the nonparametric Kruskal-Wallis analysis was implicated to compare the viral loads between MS and control groups. Statistical differences were considered significant when $p<0.05$. 


\section{RESULTS}

The PCRs. Clearly visible 308-bp internal control amplicons with similar band intensities were obtained from all RT+ samples (data not shown) excluding any troubleshooting in RNA processing. All clinical samples included in the study were negative with the PAN primers; however, the human DNA controls included in the assay were highly positive (data not shown).

The QPCRs. Despite the extreme sensitivity of our HERV QPCR assays down to few nucleic acid targets per PCR reaction, almost all outcomes of these PCRs for plasma samples were either negative or borderline. Eight of $37 \mathrm{MS}$ $(\sim 21.6 \%)$ patients, one of 43 OND patients $(\sim 2.3 \%)$ and 3 of 25 blood donors $(12.0 \%)$ were borderline reactive simultaneously with both our new HERV QPCRs and yielded negative or significantly lower signals in RT- than in RT+ reactions, which were roughly equivalent to 11-28 HERV-H copies per PCR reaction (1100-2800 viral copies per mL of plasma) and 39-74 HERV-W copies per PCR reaction (3900-7400 viral copies per $\mathrm{mL}$ of plasma), respectively (Table 3). The borderline positive sample in the OND patients group with NIPN was from a patient with spondylogenic radiculopathy, who underwent spinal surgery due to spinal stenosis one year before the investigation. All other plasma samples were negative according to our scores. In summary, 12 of 80 patient samples $(15.0 \%)$ were borderline reactive and 8 of them $(10.0 \%)$ were in the MS group. However, histone 3.3C QPCR (Andersson et al., 2005) was reactive in all of the HERV positive plasma samples, showing the presence of certain cellular RNA transcripts. All borderline reactive QPCR samples also showed weak bands of sizes appropriate for the studied HERVs on agarose gels. Moreover, all clearly negative samples were absolutely negative in gel electrophoresis analysis (data not shown). The uncertain nature of the borderline reactivity, as also the presence of histone $3.3 \mathrm{C}$ positivity, make it hard to draw definite conclusions from the results regarding the presence of retroviral particles.
In contrast with plasma samples, the tissue specific expression of HERV-H and HERV-W was characterised by strong QPCR signals and varied much. In concordance with our previous studies, HERV-H showed the highest expression in whole brain and testis, while the HERV-W group was most expressed in whole brain, uterus, trachea, adrenal gland, thyroid gland, prostate, spleen and placenta (Fig. 3) (Forsman et al., 2005).

For all PCR assays, no contamination was observed in any of the reagent control samples.

\section{DISCUSSION}

Our "story" with the controversial findings is suspiciously similar to the reports of HRV-5, SV40 and XMRV "epopees" when these viral sequences were false-positively detected in clinical samples and misassociated with certain human diseases (Griffiths et al., 2002; Forsman et al., 2003; Shah, 2007; Elfaitouri et al., 2011; Arias and Fan, 2014). In all these cases laboratory contamination was proposed as a source of doubtful weakly positive results. However, the situation with HERVs is even more "dramatic", because the human genome contains over 3000 of amplifiable HERVs copies (Lander et al., 2001). Recent ancient DNA studies have shown the huge difficulties in creating a laboratory virtually free of human DNA (Cooper and Poinar, 2000; Knapp et al., 2012). Our very stringent precautions against human and HERV DNA contamination may be the explanation of the true-negative or borderline PCR results. Additionally, frequent presence of animal and human DNA contamination of different molecular biology reagents (including those for PCRs) and laboratory consumables from different vendors has been reported (Cooper and Poinar, 2000; Leonard, 2007; Gefrides et al., 2010). As an example, the native reverse transcriptases (e.g., ALV, MuLV), which were used in some previously published studies, in contrast to recombinant enzymes (in our case), can contain the retroviral sequences and cause false-positive RT-PCR results with broadly amplifying primers (Perron et

QPCRS RESULTS FOR PLASMA SAMPLES

\begin{tabular}{|c|c|c|c|c|c|c|c|c|c|}
\hline & \multicolumn{5}{|c|}{$\begin{array}{l}\text { MS patients } \\
(\mathrm{n}=37)\end{array}$} & \multicolumn{3}{|c|}{$\begin{array}{l}\text { OND patients } \\
(\mathrm{n}=43)\end{array}$} & \multirow[t]{3}{*}{$\begin{array}{l}\mathrm{BD} \\
(\mathrm{n}=25)\end{array}$} \\
\hline & \multicolumn{2}{|c|}{$\begin{array}{c}\text { RR } \\
(n=29)\end{array}$} & \multicolumn{2}{|c|}{$\begin{array}{c}\text { SP } \\
(n=4)\end{array}$} & \multirow[t]{2}{*}{$\begin{array}{l}P P \\
(n=4)\end{array}$} & \multirow[t]{2}{*}{$\begin{array}{l}\text { IDP } \\
(n=20)\end{array}$} & \multirow[t]{2}{*}{$\begin{array}{l}\text { NIPN } \\
(\mathrm{n}=17)\end{array}$} & \multirow[t]{2}{*}{$\begin{array}{l}\text { ONIND } \\
(n=6)\end{array}$} & \\
\hline & $\begin{array}{l}\text { relapse } \\
(\mathrm{n}=26)\end{array}$ & $\begin{array}{l}\text { remission } \\
(\mathrm{n}=3)\end{array}$ & $\begin{array}{l}\text { relapse } \\
(\mathrm{n}=2)\end{array}$ & $\begin{array}{l}\text { stability } \\
(\mathrm{n}=2)\end{array}$ & & & & & \\
\hline HERVs: & $4 / 26^{*}$ & $2 / 3^{*}$ & $1 / 2 *$ & $0 / 2$ & $1 / 4 *$ & $0 / 20$ & $1 / 17 *$ & $0 / 6$ & $3 / 25^{*}$ \\
\hline Total: & \multicolumn{5}{|c|}{$\begin{array}{l}8 / 37 * \\
(\sim 21.6 \%)^{*}\end{array}$} & \multicolumn{3}{|c|}{\begin{tabular}{|l}
$1 / 43 *$ \\
$(\sim 2.3 \%)^{*}$
\end{tabular}} & $\begin{array}{l}3 / 25^{*} \\
(12.0 \%)^{*} \\
\end{array}$ \\
\hline $\begin{array}{l}\text { HERV-H: } \\
\text { (copies/mL) }\end{array}$ & \multicolumn{5}{|c|}{$2019 \pm 409$} & \multicolumn{3}{|c|}{$1100 \pm 100$} & $1917 \pm 417$ \\
\hline $\begin{array}{l}\text { HERV-W: } \\
\text { (copies/mL) }\end{array}$ & \multicolumn{5}{|c|}{$5788 \pm 850$} & \multicolumn{3}{|c|}{$3900 \pm 100$} & $5733 \pm 867$ \\
\hline
\end{tabular}

QPCRs, Real-time reverse transcription PCR assays; HERV, human endogenous retroviruses; see abbreviations also in Table 1; *Histone 3.3C positivity 

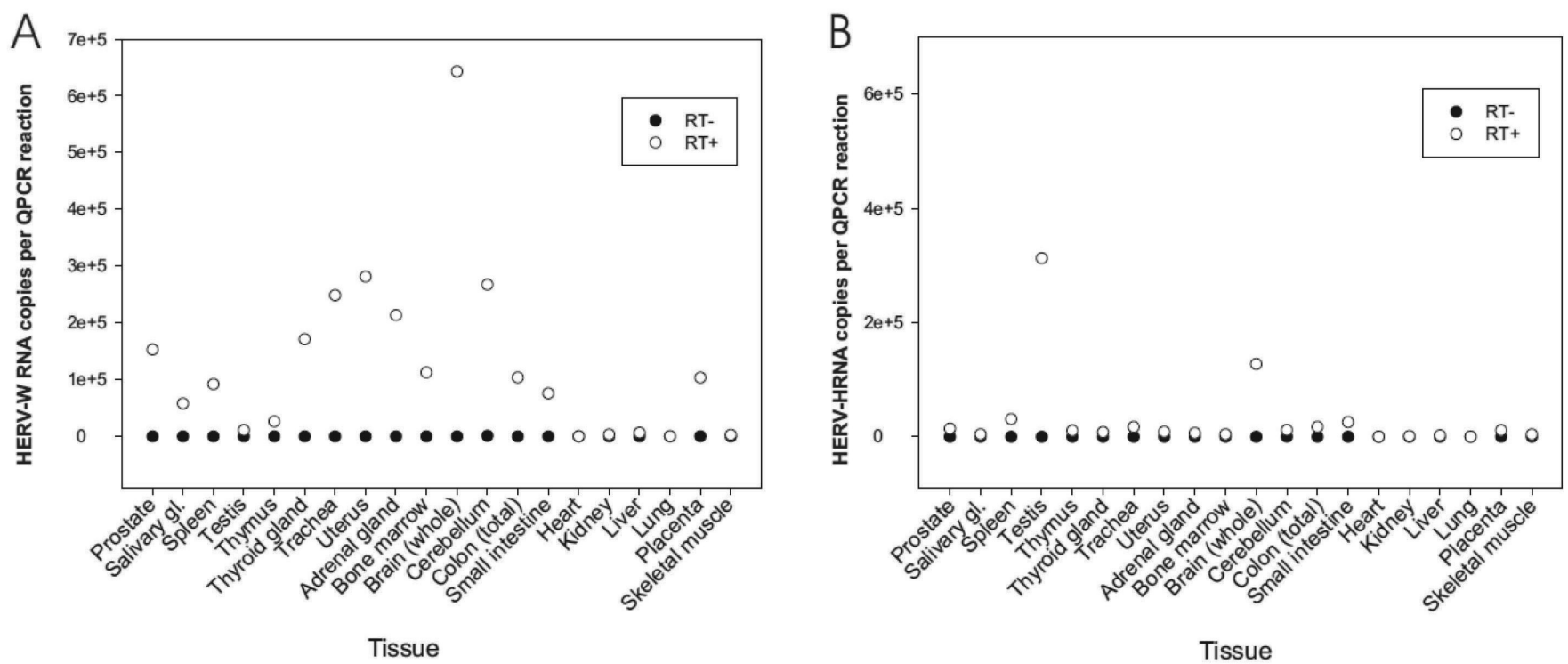

Fig. 3. Expression of HERV-H and HERV-W in twenty human tissues studied with new HERV-W (A) and HERV-H (B) QPCRs. HERV, human endogenous retroviruses. QPCRs, Real-time reverse transcription PCR assays.

al., 1997; Tuke et al., 1997). The weakness or negativity of the observed QPCR signals can be also due to the usage of a novel, hyperreactive variant of DNase I (TURBOTM DNase), thus, according to the manufacturer's data, the removal of possible DNA contamination prior to cDNA synthesis was up to 50-times more effective than in the previous studies where conventional, wild-type enzyme was used.

It is also known that, in spite of high activity of RNases in human body fluids, free circulating extracellular RNAs somehow are protected from degradation and may occur in cell-free plasma of both healthy and diseased humans (Kamm and Smith, 1972; Wieczorek et al., 1985; 1987). Thus, the borderline HERV QPCR signals detected in plasma even after extensive RNase treatment may contain a contribution from this RNA type, of which HERV transcripts may be a normal, but not the major or obligatory component. We also propose that the apoptotic bodies from dying, aged or damaged cells (Hasselmann et al., 2001; El-Hefnawy et al., 2004), as well as other extracellular vesicles (e.g., exosomes and microvesicles), which are also known to occur in plasma and serum (El-Hefnawy et al., 2004), may mimic retroviral particles in which HERV RNA could be protected from ribonucleases. Thus, artefactual PCR detection of HERV RNA in "virions" may explain the previous reports on HERV RNA in "retroviral particles". Unfortunately, in spite of the strong evidence about highly elevated levels of circulating DNA and main microRNAs (miRNAs) in MS plasma (Liggett et al., 2010; Siegel et al., 2012), there are no adequate data about the cell-free circulating RNA (cfcRNA) fraction (Unger et al., 1985) and its HERV component(s) in MS at the moment. Nevertheless, the release of microvesicles enriched in HERV nucleic acids and RT was found in the plasma of some cancer patients, as also media supernatants from certain cultured tumour cells (Bronson et al., 1979; Seifarth et al., 1995; Contreras-Galindo et al., 2008; Balaj et al., 2011). One more explanation of our negative or borderline QPCR results also could be due to occasional absence of detection because of mismatch(es) between the cDNA targets and primers or hydrolysis (TaqMan®) probes due to frequent mutations in HERV-H and HERV-W pol genes (Jern et al., 2004). However, the agarose gel electrophoresis analysis of all QPCR products, as well as highly positive, reproducible results with human tissue RNAs do not confirm this assumption (Fig. 3). The EIC also controlled for inadequate RNA extraction, degradation of isolated RNA during treatment with DNase, presence of reverse transcription and/or PCR inhibitors, as well as negligence or serious technical errors. Our findings do not exclude the presence of low amounts of retroviral RNA-containing particles (e.g., exosomes) in systemic circulation of MS patients, but advocate that this disease does not involve a systemic intense viruslike particle- or non-particle-associated HERV RNAemia. In this case, the concentration of virus-like particles on columns or gradients from a much more large volume of plasma would be very useful methodological approach. Additionally, some noteworthy data do not confirm the transcriptional activity of HERV-W in MS (Antony et al., 2006; Laufer et al., 2009; Schmitt et al., 2013) and even existence of so intensively studied Multiple Sclerosis Associated Retrovirus (MSRV) in vivo (Flockerzi et al., 2007; Laufer et al., 2009; Schmitt et al., 2013). Indeed, an absence of HERV-W or/and HERV-H RNA detection for MS plasma and CSF was reported (Antony et al., 2007; AlvarezLafuente et al., 2008). Moreover, in one study (AlvarezLafuente et al., 2008) our previously published (also used in the present work) QPCR assays were used (Forsman et al., 2005). It is hard to exclude that the negativity of the same PCR methods in our study could be due to the absence of detection of certain HERV loci. In literature, there is no convincing evidence for HERV capability to cause "virionemia" and the term "retrovirus-like particles" is overused. However, our study does not allow us to exclude that a low 
number of microvesicles from human biological fluids may indeed be of retroviral origin (Muralidharan-Chari et al., 2009).

In agreement with previous data our study also shows some upregulation of HERV-H and -W RNAs in MS plasma $(21.6 \%)$ versus controls $(5.9 \%)(p=0.02$, Fisher Exact test), but the control group was too heterogeneous, which complicates the interpretation. The "retroviral loads" of the samples which yielded a positive result were $2019 \pm 409$ vs $1713 \pm 513$ copies/mL (MS vs controls) for HERV-H and $5788 \pm 850$ vs $5275 \pm 1075$ copies/mL (MS vs controls) for HERV-W. They were not significantly different with $p<$ 0.05 , using the Kruskal-Wallis test. The HERV signals were likely of cellular origin. It is natural that cellular debris, apoptotic blebs or exosomes occur in an autoimmune disease, which inherently involves an increased frequency of cell death. No difference in the frequency of HERV-W and HERV-H RNA between different forms and stages of MS was observed (data not shown). In spite of the simultaneous detection of both HERVs in all positive clinical samples, the similar QPCRs efficiencies and detection limits, as well as the higher HERV-H versus HERV-W proviral loci number (660 and 115 copies per haploid genome, respectively) (Tristem, 2000), their "viral loads" were different (HERV-W > HERV-H, $5617 \pm 926$ vs $1917 \pm 436$ copies/mL). Possible explanations of this phenomenon may be lower transcriptional activity of HERV-H loci, a broader range for the new HERV-W QPCRs, or preferable incorporation of HERV-W transcripts into viral particles or extracellular vesicles. We speculate that the previously reported "retroviral particles" were exosomes, due to their similar size $(100 \mathrm{~nm})$ and buoyant density in a sucrose gradient (Thery et al., 2006), albeit some data posit the presence of these particles and reverse transcriptase activity in different fractions (Froussard, 1995). Thus, to clarify the origin of HERV RNA transcripts in diseased and healthy human plasma, cfcRNA, miRNAs, retrovirus-like particles (probably exosomes) and microvesicles should be individually isolated and carefully analysed for their retroviral components. Theoretically, we also cannot exclude the existence of real HERV virions co-packaged with cell RNAs (Greijer et al., 2000; Sciortino et al., 2001) and even the formation of complex chimeric virions containing a "cocktail" of multiple retroviral RNAs (e.g. HERV-H and -W together) with cellular transcripts in vivo. However, in our opinion, the low "viral loads" and simultaneous detection of both HERVs and nonretroviral RNAs in the MS samples makes it rather hard to attribute the QPCRs findings to the production of virions. We may speculate that the previous findings were experimental artifacts or drafts due to laboratory flaws. Even in our hands, while we rigorously removed DNA from RNA preparations and very carefully verified the absence of DNA contamination in all QPCR experiments, it is nevertheless very difficult to remove all DNA traces from RNA preparations. One therefore cannot formally exclude the presence of some residual DNA in the RNA used for cDNA generation. Moreover, the effect of interindividual variations (Nellaker et al., 2009), ethnical (Arru et al., 2007), age- and therapy-specific factors (Diem et al., 2012; Liu et al., 2013; Arru et al., 2014; Balestrieri et al., 2015), as also MS clinical forms and disease severity (Garcia-Montojo et al., 2013; 2014) on the expression and release of HERV RNAs into the bloodstream cannot be excluded. Thus, one of the falsification criteria for one of the models for retrovirally caused disease in MS may be fulfilled (Blomberg et al., 2005). The optimised methods can be useful for understanding of the pathobiology of HERV-H and HERV-W. The study also illustrates the methodological difficulties of getting and interpreting reliable HERV PCR results, especially in patients with cytopathic diseases. In our opinion, to further elucidate the possible physiopathological functions of HERVs, there is a need for several carefully designed, preferably prospective, studies methodologically harmonised between all investigators.

\section{ACKNOWLEDGMENTS}

This work was supported by the Swedish Scientific Council (Grant \# K2004-32X-14252), the Swedish Institute (Grant East-92 380/133 and 351) and the Latvian Council of Science (Grant 04.1157). The development of the QPCRs was supported by the Stanley Foundation (Grants \# 02R-376 and \#03R-584). The funding sources had no role in the experimental design, sample collection, analyses, data interpretation, as also writing of the report and decision to submit the paper for publication. The authors declare no conflict of interest.

\section{REFERENCES}

Altschul, S. F., Madden, T. L., Schaffer, A. A., Zhang, J., Zhang, Z., Miller, W., Lipman, D. J. (1997). Gapped BLAST and PSI-BLAST: A new generation of protein database search programs. Nucleic Acids Res., 25 (17), 3389-3402. Available at: http://www.ncbi.nlm.nih.gov/pubmed/9254694 (accessed 27.05.2016).

Alvarez-Lafuente, R., Garcia-Montojo, M., De Las Heras, V., DominguezMozo, M. I., Bartolome, M., Benito-Martin, M. S., Arroyo, R. (2008). Herpesviruses and human endogenous retroviral sequences in the cerebrospinal fluid of multiple sclerosis patients. Mult. Scler., 14 (5), 595-601.

Andersson, A. C., Yun, Z., Sperber, G. O., Larsson, E., Blomberg, J. (2005). ERV3 and related sequences in humans: Structure and RNA expression. $J$. Virol., 79 (14), 9270-9284.

Antony, J. M., Izad, M., Bar-Or, A., Warren, K. G., Vodjgani, M., Mallet, F., Power, C. (2006). Quantitative analysis of human endogenous retrovirus-W env in neuroinflammatory diseases. AIDS Res. Hum. Retroviruses, 22 (12), 1253-1259

Antony, J. M., Zhu, Y., Izad, M., Warren, K. G., Vodjgani, M., Mallet, F., Power, C. (2007). Comparative expression of human endogenous retrovirus-W genes in multiple sclerosis. AIDS Res. Hum. Retroviruses, 23 (10), 1251-1256.

Arias, M., Fan, H. (2014). The saga of XMRV: A virus that infects human cells but is not a human virus. Emerg. Microbes Infect., 3 (4), e.

Arru, G., Leoni, S., Pugliatti, M., Mei, A., Serra, C., Delogu, L. G., Manetti, R., Dolei, A., Sotgiu, S., Mameli, G. (2014). Natalizumab inhibits the expression of human endogenous retroviruses of the $\mathrm{W}$ family in multiple sclerosis patients: A longitudinal cohort study. Mult. Scler., 20 (2), 174-182. 
Arru, G., Mameli, G., Astone, V., Serra, C., Huang, Y. M., Link, H., Fainardi, E., Castellazzi, M., Granieri, E., Fernandez, M., Villoslada, P., Fois, M. L., Sanna, A., Rosati, G., Dolei, A., Sotgiu, S. (2007). Multiple Sclerosis and HERV-W/MSRV: A Multicentric Study. Int. J. Biomed. Sci., 3 (4), 292-297.

Asbury, A. K., Cornblath, D. R. (1990). Assessment of current diagnostic criteria for Guillain-Barre syndrome. Ann. Neurol., 27 Suppl., S21-24. Available at: http://www.ncbi.nlm.nih.gov/pubmed/2194422 (accessed 27.05.2016).

Balaj, L., Lessard, R., Dai, L., Cho, Y. J., Pomeroy, S. L., Breakefield, X. O., Skog, J. (2011). Tumour microvesicles contain retrotransposon elements and amplified oncogene sequences. Nat. Commun., 2, 180.

Balestrieri, E., Pica, F., Matteucci, C., Zenobi, R., Sorrentino, R., ArgawDenboba, A., Cipriani, C., Bucci, I., Sinibaldi-Vallebona, P. (2015). Transcriptional activity of human endogenous retroviruses in human peripheral blood mononuclear cells. Biomed. Res. Int., 2015, 164529.

Blomberg, J., Ushameckis, D., Jern, P. (2005). Evolutionary aspects of human endogenous retroviral sequences (HERVs) and disease. In: Sverdlov, E. D. (Ed.). Retroviruses and Primate Genome Evolution. Landes Bioscience, Austin, TX, USA, pp. 204-238.

Bronson, D. L., Fraley, E. E., Fogh, J., Kalter, S. S. (1979). Induction of retrovirus particles in human testicular tumor (Tera-1) cell cultures: An electron microscopic study. J. Natl. Cancer Inst., 63 (2), 337-339. Available at: http://www.ncbi.nlm.nih.gov/pubmed/287828 (accessed 27.05.2016).

Bustin, S. A., Benes, V., Garson, J. A., Hellemans, J., Huggett, J., Kubista, M., . . . Wittwer, C. T. (2009). The MIQE guidelines: Minimum information for publication of quantitative real-time PCR experiments. Clin. Chem., 55 (4), 611-622.

Chomczynski, P., Mackey, K. (1995). Substitution of chloroform by bromo-chloropropane in the single-step method of RNA isolation. Anal. Biochem., 225 (1), 163-164.

Christensen, T. (2005). Association of human endogenous retroviruses with multiple sclerosis and possible interactions with herpes viruses. Rev. Med. Virol., 15 (3), 179-211.

Christensen, T., Dissing Sorensen, P., Riemann, H., Hansen, H. J., Munch, M., Haahr, S., Moller-Larsen, A. (2000). Molecular characterization of HERV-H variants associated with multiple sclerosis. Acta Neurol. Scand., 101 (4), 229-238.

Christensen, T., Jensen, A. W., Munch, M., Haahr, S., Sorensen, P. D., Riemann, H., Hansen, H. J., Moller-Larsen, A. (1997). Characterization of retroviruses from patients with multiple sclerosis. Acta Neurol. Scand. Suppl., 169, 49-58

Christensen, T., Pedersen, L., Sorensen, P. D., Moller-Larsen, A. (2002). A transmissible human endogenous retrovirus. AIDS Res. Hum. Retroviruses, 18 (12), 861-866.

Christensen, T., Tonjes, R. R., zur Megede, J., Boller, K., Moller-Larsen, A. (1999). Reverse transcriptase activity and particle production in B lymphoblastoid cell lines established from lymphocytes of patients with multiple sclerosis. AIDS Res. Hum. Retroviruses, 15 (3), 285-291.

Compston, A., Coles, A. (2008). Multiple sclerosis. Lancet, 372 (9648), 1502-1517.

Contreras-Galindo, R., Kaplan, M. H., Leissner, P., Verjat, T., Ferlenghi, I., Bagnoli, F., Dosik, M.. H., Hayes, D. F., Gitlin, S. D., Markovitz, D. M. (2008). Human endogenous retrovirus K (HML-2) elements in the plasma of people with lymphoma and breast cancer. J. Virol., 82 (19), 9329-9336.

Cooper, A., Poinar, H. N. (2000). Ancient DNA: Do it right or not at all. Science, 289 (5482), 1139

de Villiers, J. N., Treurnicht, F. K., Warnich, L., Carr, J., van Rensburg, S. J., Kotze, M. J. (2006). Analysis of viral and genetic factors in South African patients with multiple sclerosis. Metab. Brain Dis., 21 (2-3), 163-169.
Diem, O., Schaffner, M., Seifarth, W., Leib-Mosch, C. (2012). Influence of antipsychotic drugs on human endogenous retrovirus (HERV) transcription in brain cells. PLoS One, 7 (1), e30054.

Dolei, A., Serra, C., Mameli, G., Pugliatti, M., Sechi, G., Cirotto, M. C., Rosati, G., Sotgiu, S. (2002). Multiple sclerosis-associated retrovirus (MSRV) in Sardinian MS patients. Neurology, 58 (3), 471-473.

El-Hefnawy, T., Raja, S., Kelly, L., Bigbee, W. L., Kirkwood, J. M., Luketich, J. D., Godfrey, T. E. (2004). Characterization of amplifiable, circulating RNA in plasma and its potential as a tool for cancer diagnostics. Clin. Chem., 50 (3), 564-573.

Elfaitouri, A., Shao, X., Mattsson Ulfstedt, J., Muradrasoli, S., Bolin Wiener, A., Golbob, S., Ohrmalm, C., Matousek, M., Zachrisson, O., Gottfries, C. G., Blomberg, J. (2011). Murine gammaretrovirus group G3 was not found in Swedish patients with myalgic encephalomyelitis/chronic fatigue syndrome and fibromyalgia. PLoS One, 6 (10), e24602.

Flockerzi, A., Maydt, J., Frank, O., Ruggieri, A., Maldener, E., Seifarth, W., Medstrand, P., Lengauer, T., Meyerhans, A., Leib-Mösch, C., Meese, E., Mayer, J. (2007). Expression pattern analysis of transcribed HERV sequences is complicated by ex vivo recombination. Retrovirology, 4, 39 .

Forsman, A., Yun, Z., Hu, L., Uzhameckis, D., Jern, P., Blomberg, J. (2005). Development of broadly targeted human endogenous gammaretroviral pol-based real time PCRs Quantitation of RNA expression in human tissues. J. Virol. Methods, 129 (1), 16-30.

Forsman, A., Uzameckis, D., Ronnblom, L., Baecklund, E., Aleskog, A., Bindra, A., Pipkorn, R., Lejniece, S., Kozireva, S., Murovska, M., Blomberg, J. (2003). Single-tube nested quantitative PCR: A rational and sensitive technique for detection of retroviral DNA. Application to RERV-H/HRV-5 and confirmation of its rabbit origin. J. Virol. Methods, 111 (1), 1-11

Freeman, G. H., Halton, J. H. (1951). Note on an exact treatment of contingency, goodness of fit and other problems of significance. Biometrika, 38 (1-2), 141-149. Available at: http://www.ncbi.nlm.nih.gov/pubmed/14848119 (accessed 27.05.2016).

Froussard, P. (1995). Is LM7 a new human retrovirus or a mycoplasma virion? Mult. Scler., 1 (2), 88-94.

Garcia-Montojo, M., de la Hera, B., Varade, J., de la Encarnacion, A., Camacho, I., Dominguez-Mozo, M., Árias-Leal, A., García-Martínez, A., Casanova, I., Izquierdo, G., Lucas, M., Fedetz, M., Alcina, A., Arroyo, R. Matesanz, F., Urcelay, E. Alvarez-Lafuente, R. (2014). HERV-W polymorphism in chromosome $\mathrm{X}$ is associated with multiple sclerosis risk and with differential expression of MSRV. Retrovirology, 11, 2.

Garcia-Montojo, M., Dominguez-Mozo, M., Arias-Leal, A., Garcia-Martinez, A., De las Heras, V., Casanova, I., Faucard, R., Gehin, N., Madeira, A., Arroyo, R., Curtin, F., Alvarez-Lafuente, R., Perron, H. (2013). The DNA copy number of human endogenous retrovirus-W (MSRV-type) is increased in multiple sclerosis patients and is influenced by gender and disease severity. PLoS One, 8 (1), e53623.

Garson, J. A., Tuke, P. W., Giraud, P., Paranhos-Baccala, G., Perron, H (1998). Detection of virion-associated MSRV-RNA in serum of patients with multiple sclerosis. Lancet, 351 (9095), 33

Gefrides, L. A., Powell, M. C., Donley, M. A., Kahn, R. (2010). UV irradiation and autoclave treatment for elimination of contaminating DNA from laboratory consumables. Forensic Sci. Int. Genet., 4 (2), 89-94

Gifford, R., Tristem, M. (2003). The evolution, distribution and diversity of endogenous retroviruses. Virus Genes, 26 (3), 291-315.

Greijer, A. E., Dekkers, C. A., Middeldorp, J. M. (2000). Human cytomegalovirus virions differentially incorporate viral and host cell RNA during the assembly process. J. Virol., 74 (19), 9078-9082. Available at: http://www.ncbi.nlm.nih.gov/pubmed/10982353 (accessed 27.05.2016).

Griffiths, D. J., Voisset, C., Venables, P. J., Weiss, R. A. (2002). Novel endogenous retrovirus in rabbits previously reported as human retrovirus 5. J. Virol., 76 (14), 7094-7102. 
Haahr, S., Sommerlund, M., Christensen, T., Jensen, A. W., Hansen, H. J., Moller-Larsen, A. (1994). A putative new retrovirus associated with multiple sclerosis and the possible involvement of Epstein-Barr virus in this disease. Ann. NY Acad. Sci., 724, 148-156.

Hasselmann, D. O., Rappl, G., Tilgen, W., Reinhold, U. (2001). Extracellular tyrosinase mRNA within apoptotic bodies is protected from degradation in human serum. Clin. Chem., 47 (8), 1488-1489. Available at: http://www.ncbi.nlm.nih.gov/pubmed/11468248 (accessed 27.05.2016).

Jern, P., Sperber, G. O., Ahlsen, G., Blomberg, J. (2005). Sequence variability, gene structure, and expression of full-length human endogenous retrovirus H. J. Virol., 79 (10), 6325-6337.

Jern, P., Sperber, G. O., Blomberg, J. (2004). Definition and variation of human endogenous retrovirus H. Virology, 327 (1), 93-110.

Kamm, R. C., Smith, A. G. (1972). Nucleic acid concentrations in normal human plasma. Clin. Chem., 18 (6), 519-522. Available at: http://www.ncbi.nlm.nih.gov/pubmed/5026765 (accessed 27.05.2016).

Kim, H. S. (2001). Sequence and phylogeny of HERV-W pol fragments. AIDS Res. Hum. Retroviruses, 17 (17), 1665-1671.

Knapp, M., Clarke, A. C., Horsburgh, K. A., Matisoo-Smith, E. A. (2012). Setting the stage - building and working in an ancient DNA laboratory. Ann. Anat., 194 (1), 3-6.

Komurian-Pradel, F., Paranhos-Baccala, G., Bedin, F., Ounanian-Paraz, A., Sodoyer, M., Ott, C., Rajoharison, A., Garcia, E., Mallet, F., Mandrand, B., Perron, H. (1999). Molecular cloning and characterization of MSRV-related sequences associated with retrovirus-like particles. Virology, 260 (1), $1-9$.

Kurtzke, J. F. (2000). Epidemiology of multiple sclerosis. Does this really point towards an etiology? Neurol. Sci, 21, 383-403.

Lander, E. S., Linton, L. M., Birren, B., Nusbaum, C., Zody, M. C., Baldwin, J., ... International Human Genome Sequencing Consortium (2001). Initial sequencing and analysis of the human genome. Nature, 409 (6822), 860-921.

Laufer, G., Mayer, J., Mueller, B. F., Mueller-Lantzsch, N., Ruprecht, K. (2009). Analysis of transcribed human endogenous retrovirus W env loci clarifies the origin of multiple sclerosis-associated retrovirus env sequences. Retrovirology, 6, 37.

Leonard, J. A., Shanks, O., Hofreiter, M., Kreuz, E., Hodges, L., Ream, W., Wayne, R. K., Fleischer, R. C. (2007). Animal DNA in PCR reagents plagues ancient DNA research. J. Archaeol. Sci., 34 (9), 1361-1366.

Liggett, T., Melnikov, A., Tilwalli, S., Yi, Q., Chen, H., Replogle, C., Feng, X., Reder, A., Stefoski, D., Balabanov, R., Levenson, V. (2010). Methylation patterns of cell-free plasma DNA in relapsing-remitting multiple sclerosis. J. Neurol. Sci., 290 (1-2), 16-21.

Lindeskog, M., Medstrand, P., Cunningham, A. A., Blomberg, J. (1998). Coamplification and dispersion of adjacent human endogenous retroviral HERV-H and HERV-E elements; presence of spliced hybrid transcripts in normal leukocytes. Virology, 244 (1), 219-229.

Liu, C., Chen, Y., Li, S., Yu, H., Zeng, J., Wang, X., Zhu, F. (2013). Activation of elements in HERV-W family by caffeine and aspirin. Virus Genes, 47 (2), 219-227.

Lo, Y. M., Chan, K. C. (2006). Setting up a polymerase chain reaction laboratory. Methods Mol. Biol., 336, 11-18.

Longo, M. C., Berninger, M. S., Hartley, J. L. (1990). Use of uracil DNA glycosylase to control carry-over contamination in polymerase chain reactions. Gene, 93 (1), 125-128.

Munch, M., Moller-Larsen, A., Christensen, T., Morling, N., Hansen, H. J., Haahr, S. (1995). B-lymphoblastoid cell lines from multiple sclerosis patients and a healthy control producing a putative new human retrovirus and Epstein-Barr virus. Mult. Scler., 1 (2), 78-81.

Muralidharan-Chari, V., Clancy, J., Plou, C., Romao, M., Chavrier, P., Raposo, G., D'Souza-Schorey, C. (2009). ARF6-regulated shedding of tu- mor cell-derived plasma membrane microvesicles. Curr. Biol., 19 (22), 1875-1885.

Nellaker, C., Li, F., Uhrzander, F., Tyrcha, J., Karlsson, H. (2009). Expression profiling of repetitive elements by melting temperature analysis: Variation in HERV-W gag expression across human individuals and tissues. BMC Genomics, 10, 532.

Nowak, J., Januszkiewicz, D., Pernak, M., Liwen, I., Zawada, M., Rembowska, J., Nowicka, K., Lewandowski, K., Hertmanowska, H.,Wender, M. (2003). Multiple sclerosis-associated virus-related pol sequences found both in multiple sclerosis and healthy donors are more frequently expressed in multiple sclerosis patients. J. Neurovirol., 9 (1), 112-117.

Ou, C. Y., Moore, J. L., Schochetman, G. (1991). Use of UV irradiation to reduce false positivity in polymerase chain reaction. Biotechniques, 10 (4), $442,444,446$.

Perron, H., Garson, J. A., Bedin, F., Beseme, F., Paranhos-Baccala, G., Komurian-Pradel, F., Mallet, F., Tuke, P. W., Voisset, C., Blond, J. L., Lalande, B., Seigneurin, J. M., Mandrand, B. (1997). Molecular identification of a novel retrovirus repeatedly isolated from patients with multiple sclerosis. The Collaborative Research Group on Multiple Sclerosis. Proc. Natl. Acad. Sci. USA, 94 (14), 7583-7588.

Perron, H., Geny, C., Laurent, A., Mouriquand, C., Pellat, J., Perret, J., Seigneurin, J. M. (1989). Leptomeningeal cell line from multiple sclerosis with reverse transcriptase activity and viral particles. Res. Virol., 140 (6), $551-561$.

Perron, H., Lalande, B., Gratacap, B., Laurent, A., Genoulaz, O., Geny, C., Mallaret, M., Schuller, E., Stoebner, P., Seigneurin, J. M. (1991). Isolation of retrovirus from patients with multiple sclerosis. Lancet, 337 (8745), $862-863$.

Perron, H., Perin, J. P., Rieger, F., Alliel, P. M. (2000). Particle-associated retroviral RNA and tandem RGH/HERV-W copies on human chromosome 7q: Possible components of a 'chain-reaction' triggered by infectious agents in multiple sclerosis? J. Neurovirol., 6 (Suppl 2), S67-75.

Polman, C. H., Reingold, S. C., Edan, G., Filippi, M., Hartung, H. P., Kappos, L., Lublin, F. D., Metz, L. M., McFarland, H. F., O'Connor, P. W., Sandberg-Wollheim, M., Thompson, A. J., Weinshenker, B. G., Wolinsky, J. S. (2005). Diagnostic criteria for multiple sclerosis: 2005 revisions to the "McDonald Criteria". Ann. Neurol., 58 (6), 840-846.

Pruvost, M., Grange, T., Geigl, E. M. (2005). Minimizing DNA contamination by using UNG-coupled quantitative real-time PCR on degraded DNA samples: Application to ancient DNA studies. Biotechniques, 38 (4), 569-575.

Pugliatti, M., Rosati, G., Carton, H., Riise, T., Drulovic, J., Vecsei, L., Milanov, I. (2006). The epidemiology of multiple sclerosis in Europe. Eur. J. Neurol., 13 (7), 700-722.

Schmitt, K., Richter, C., Backes, C., Meese, E., Ruprecht, K., Mayer, J. (2013). Comprehensive analysis of human endogenous retrovirus group HERV-W locus transcription in multiple sclerosis brain lesions by high-throughput amplicon sequencing. J. Virol., 87 (24), 13837-13852.

Sciortino, M. T., Suzuki, M., Taddeo, B., Roizman, B. (2001). RNAs extracted from herpes simplex virus 1 virions: Apparent selectivity of viral but not cellular RNAs packaged in virions. J. Virol., 75 (17), 8105-8116. Available at: http://www.ncbi.nlm.nih.gov/pubmed/11483756 (accessed 27.05.2016).

Seifarth, W., Skladny, H., Krieg-Schneider, F., Reichert, A., Hehlmann, R., Leib-Mosch, C. (1995). Retrovirus-like particles released from the human breast cancer cell line T47-D display type B- and C-related endogenous retroviral sequences. J Virol, 69 (10), 6408-6416. Available at: http://www.ncbi.nlm.nih.gov/pubmed/7545247 (accessed 27.05.2016).

Serra, C., Sotgiu, S., Mameli, G., Pugliatti, M., Rosati, G., Dolei, A. (2001). Multiple sclerosis and multiple sclerosis-associated retrovirus in Sardinia. Neurol. Sci., 22 (2), 171-173.

Shah, K. V. (2007). SV40 and human cancer: A review of recent data. Int. J. Cancer, 120 (2), 215-223. 
Siegel, S. R., Mackenzie, J., Chaplin, G., Jablonski, N. G., Griffiths, L. (2012). Circulating microRNAs involved in multiple sclerosis. Mol. Biol. Rep., 39 (5), 6219-6225.

Soper, D. S. (2015). Fisher's Exact Test Calculator for a 3X3 Contingency Table [Software]. Available at: http://www.danielsoper.com/statcalc (accessed 27.05.2016).

Sperber, G., Lovgren, A., Eriksson, N. E., Benachenhou, F., Blomberg, J. (2009). RetroTector online, a rational tool for analysis of retroviral elements in small and medium size vertebrate genomic sequences. $B M C$ Bioinformatics, 10 (Suppl 6), S4.

Sperber, G. O., Airola, T., Jern, P., Blomberg, J. (2007). Automated recognition of retroviral sequences in genomic data - RetroTector. Nucleic Acids Res., 35 (15), 4964-4976.

Tamariz, J., Voynarovska, K., Prinz, M., Caragine, T. (2006). The application of ultraviolet irradiation to exogenous sources of DNA in plasticware and water for the amplification of low copy number DNA. J. Forensic Sci., 51 (4), 790-794.

Thery, C., Amigorena, S., Raposo, G., Clayton, A. (2006). Isolation and characterization of exosomes from cell culture supernatants and biological fluids. Curr. Protoc. Cell Biol., Chapt. 3, Unit 322.

Thompson, J. D., Higgins, D. G., Gibson, T. J. (1994). CLUSTAL W: improving the sensitivity of progressive multiple sequence alignment through sequence weighting, position-specific gap penalties and weight matrix choice. Nucleic Acids Res., 22 (22), 4673-4680. Available at: http://www.ncbi.nlm.nih.gov/pubmed/7984417 (accessed 27.05.2016).
Tristem, M. (2000). Identification and characterization of novel human endogenous retrovirus families by phylogenetic screening of the human genome mapping project database. J. Virol., 74 (8), 3715-3730.

Tuke, P. W., Perron, H., Bedin, F., Beseme, F., Garson, J. A. (1997). Development of a pan-retrovirus detection system for multiple sclerosis studies. Acta Neurol. Scand. Suppl., 169, 16-21. Available at: http://www.ncbi.nlm.nih.gov/pubmed/9174636 (accessed 27.05.2016).

Unger, M., Wettergren, A., Clausen, J. (1985). Characterization of DNA and RNA in circulating immunocomplexes in multiple sclerosis, amyotrophic lateral sclerosis and normal controls. Acta Neurol. Scand., 72 (4), 392-396. Available at: http://www.ncbi.nlm.nih.gov/pubmed/2417439 (accessed 27.05.2016)

Vandesompele, J., De Preter, K., Pattyn, F., Poppe, B., Van Roy, N., De Paepe, A., Speleman, F. (2002). Accurate normalization of real-time quantitative RT-PCR data by geometric averaging of multiple internal control genes. Genome Biol., 3 (7), RESEARCH0034. Available at: http://www.ncbi.nlm.nih.gov/pubmed/12184808 (accessed 27.05.2016).

Wieczorek, A. J., Rhyner, C., Block, L. H. (1985). Isolation and characterization of an RNA-proteolipid complex associated with the malignant state in humans. Proc. Natl. Acad. Sci. USA, 82 (10), 3455-3459. Available at: http://www.ncbi.nlm.nih.gov/pubmed/2582412 (accessed 27.05.2016).

Wieczorek, A. J., Sitaramam, V., Machleidt, W., Rhyner, K., Perruchoud, A. P., Block, L. H. (1987). Diagnostic and prognostic value of RNA-proteolipid in sera of patients with malignant disorders following therapy: First clinical evaluation of a novel tumor marker. Cancer Res., 47 (23), 6407-6412. Available at:

http://www.ncbi.nlm.nih.gov/pubmed/2445471 (accessed 27.05.2016).

Received 26 October 2015

\section{NAV APSTIPRINOŠU PIERĀDĪJUMU PAR ENDOGĒNO RETROVĪRUSU HERV-W UN HERV-H RNS SASTOPAMĪBU LATVIJAS PACIENTU AR MULTIPLO SKLEROZI UN CITĀM NEIROLOĢISKĀM SLIMĪBĀM ASINS PLAZMĀ}

Multiplā skleroze (MS) ir neiroloǵiska slimība ar nezināmu etioloǵiju. Dažas pētnieku grupas ir ziṇojušas par divu cilvēka endogēno retrovīrusu HERV-W un HERV-H paaugstinātu RNS līmeni cerebrospinālajā škidrumā, asins plazmā un šūnu kultūru supernatantā, kas iegūti no MS pacientiem. Abu HERV ekstracelulāro vīrusspecifisko RNS kvantitatīvai noteikšanai Latvijas MS pacientu un pacientu ar citām neiroloğiskām slimībām asins plazmas paraugos tika lietotas gan mūsu iepriekš publicêtas, gan arī jaunizstrādātas kvantitatīvas reālā laika apgrieztās transkripcijas PCR (polymerase chain reaction, polimerāzes ķēdes reakcija) metodes (QPCRs) ar praimeriem un zondēm, kas ir komplementāras dažādiem HERV-W un HERV-H polimerāzes ( $p o l$ ) gēna rajoniem. Lai izslēgtu nespecifisku HERV signālu esamību, kas rodas sakarā ar nepilnīgu šūnu DNS degradēšanu RNS paraugos, paralēli tika veiktas QPCRs ar un bez apgrieztās

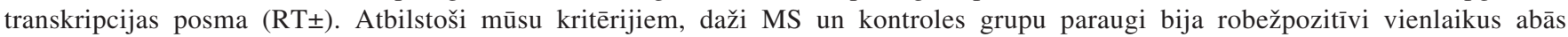
jaunizstrādātajās HERV-H un HERV-W QPCRs, bet pārējie bija negatīvi. Visi šie robežpozitīvie paraugi saturēja nelielu šūnu iRNS daudzumu ar iespējamu izcelsmi no asinīs cirkulējošas šūnām brīvas RNS, apoptotiskiem ķermenīšiem vai ekzosomām, kas var mimikrēt iepriekš aprakstītās vīrusiem līdzīgās daḷiņas. Iegūtie rezultāti neapstiprina iepriekš publicētos datus par HERV-H un HERV-W vīrusasociētās RNS sastopamību MS pacientu asins plazmā. 